\title{
Cool Cities: Counteracting Potential Climate Change and its Health Impacts
}

\author{
Haider Taha ${ }^{1}$
}

Published online: 16 July 2015

(C) Springer International Publishing AG 2015

\begin{abstract}
Cool cities can produce a range of multi-scale, multi-dimensional impacts on the atmospheric environment. One area of increasing interest is the potentially beneficial impacts of cool cities in reducing heat stress and improving air quality health during hot weather and heat events. While the overriding effects of cool cities are beneficial in terms of thermal environment, cooling-energy use, air pollutant emissions, atmospheric chemistry, and air quality, some inadvertent effects can also arise. The goal of this paper is to present and compare the magnitudes of local heat and air quality effects induced by (1) climate change, (2) urban heat islands, and (3) cool cities. From the review of past and more recent findings, this paper concludes that cool cities have the potential to offset the negative local health impacts of climate change and/or their exacerbation by urban areas. To achieve these benefits, the measures must be tailored to region-specific characteristics and needs.
\end{abstract}

Keywords Air quality - Air quality index - Atmospheric modeling $\cdot$ Climate change $\cdot$ Cool cities $\cdot$ Heat health $\cdot$ Heat index $\cdot$ Heat island control $\cdot$ Urban climate $\cdot$ Urban cooling . Urban heat islands

This article is part of the Topical Collection on Climate Change and Human Health

Haider Taha

haider@altostratus.com

1 Altostratus Inc., 940 Toulouse Way, Martinez, CA 94553, USA

\section{Introduction}

One anticipated outcome of climate change is an increase in frequency and duration of heat events $[1,2]$. While these events are defined differently in different regions [3], all require certain temperature thresholds to be exceeded, the compounding effect of humidity be considered, and that they have certain intensity, duration, and spatial-extent characteristics [4]. Many studies project significant health implications from such conditions. For example, a study of 12 U.S. cities estimates that by the end of the century, up to 200,000 heatrelated deaths will occur in these urban areas because of climate change $[5,6]$. During the California heat wave of 2006, there was a $9 \%$ increase in daily mortality rate for each $5.5^{\circ} \mathrm{C}$ $\left(10^{\circ} \mathrm{F}\right)$ increase in apparent temperature [7].

The climate change impacts on heat stress, emissions, and atmospheric pollution can be further exacerbated by urban heat islands (UHIs) because of the higher canopy- and boundary-layer temperatures, transport of heat and pollutants, reduced surface moisture, and modified cloudiness. These pathways, separately and synergistically, impact heat and air quality health.

UHIs can be defined or diagnosed in different manners including, for example, as instantaneous or cumulative metrics, point-specific or area-averaged, relative to fixed or timevarying (wind-dependent) temperature reference points, and with or without pre-defined temperature thresholds. UHIs also vary in intensity and diurnal/seasonal profiles as well as in spatiotemporal characteristics. Instantaneous UHIs are most often in the range of $0.5-3^{\circ} \mathrm{C}[8,9 \bullet, 10 \bullet, 11,12]$. Larger UHIs, e.g., $4-8^{\circ} \mathrm{C}$, have been observed $[13,14]$ but are not considered typical. Cool islands (UCI), when cities are cooler than non-urban surroundings, can occur during certain parts of the day, e.g., early morning [11], or on seasonal time scales [15], but UHIs occur much more frequently [8]. And while UHIs 
can be an asset in high-latitude climates, they are a liability in terms of energy, heat, emissions, and air quality in the midand low latitudes. Thus, where UHIs exist in these regions, it is desirable to mitigate them.

Presently, there exists a global interest in implementing cool cities [16]. Whether these measures can offset part or all of the urban and local climate effects will depend on each region's characteristics. However, cool cities can produce desired environmental benefits (cooling) regardless of the existence of a UHI, i.e., even when urban areas are UCIs [11].

Figure 1 depicts the general pathways discussed in this paper. While climate change will impact all local meteorological fields, the main focus in this paper is on the changes in air temperature. Urban areas can locally exacerbate $(+)$ the climate effects and increase temperature further. Cool cities can lower temperatures (-) and mitigate the health effects. The dashed line suggests that cool cities can also indirectly impact the global climate via reducing emissions of greenhouse gases and their subsequent intercontinental transport.

\section{Cool Cities Measures}

While many technologies could be considered part of the cool cities portfolio of strategies, Table 1 lists some of the more common ones, along with their influence pathways [17•, 20•]. These measures, whether standalone or in combinations, can affect regional meteorology, microclimate, emissions, and chemistry in varying degrees and, thus, directly and/or indirectly heat and air quality health.

Thus, urban areas or neighborhoods that deploy some or all of these measures are defined as cool cities. In terms of atmospheric and environmental impacts, cool cities are defined as the horizontal and vertical domains within which the effects from these measures are detected, e.g., on micrometeorology (temperature, moisture, and wind), emissions (anthropogenic and biogenic), and chemistry (air quality).
The beneficial effects (cooling and improved air quality) of the measures in Table 1 are mainly localized effects, i.e., experienced directly at and near where cool cities measures are deployed. Downwind of the modified areas, effects are generally positive but sometimes also negative, e.g., warming and/ or increased ozone [8, 11]. Furthermore, the effectiveness of cool cities varies significantly from one geographical area to another, depending on climate, emissions profiles, technical potential, and size of modified urban area. Accordingly, the deployment of these technologies should be tailored to areaspecific characteristics so as to maximize health benefits.

\section{Positive and Negative Impacts of Cool Cities}

As with many environmental control measures, cool cities can exert both positive (beneficial) and negative (inadvertent) effects. The benefits include reduced cooling energy demand, improved thermal comfort, reduced emissions of air pollutants, and improved air quality [35]. Inadvertent effects include winter heating energy penalties and increased temperature and/or pollutant concentrations downwind of cool cities [18].

\section{Regional Scale}

Modeling studies at the regional, urban, and microscales [11, $18,23]$ show that the inadvertent effects are smaller than the beneficial ones and limited in spatial extent. For example, the implementation of various cool cities measures (e.g., those listed in Table 1) in California could lead to typical decreases of $0.5-3.0{ }^{\circ} \mathrm{C}$ in daytime air temperature and average reductions of $\sim 6$ degree-hour per day $\left(\mathrm{dh} \mathrm{day}^{-1}\right.$ ) above $15^{\circ} \mathrm{C}$ [36]. The decreases in 1-h average ozone can reach up to 10 $15 \mathrm{ppb}$. The negative effects, mostly downwind of cool cities, include (1) increased temperature (up to $\sim 0.3{ }^{\circ} \mathrm{C}$ ) due to inhibited mixing and (2) increased ozone (2-3 ppb) due to reduced venting, higher temperatures, and shallower boundary layers, although the latter can cause both increases and

Fig. 1 Pathways discussed in this paper

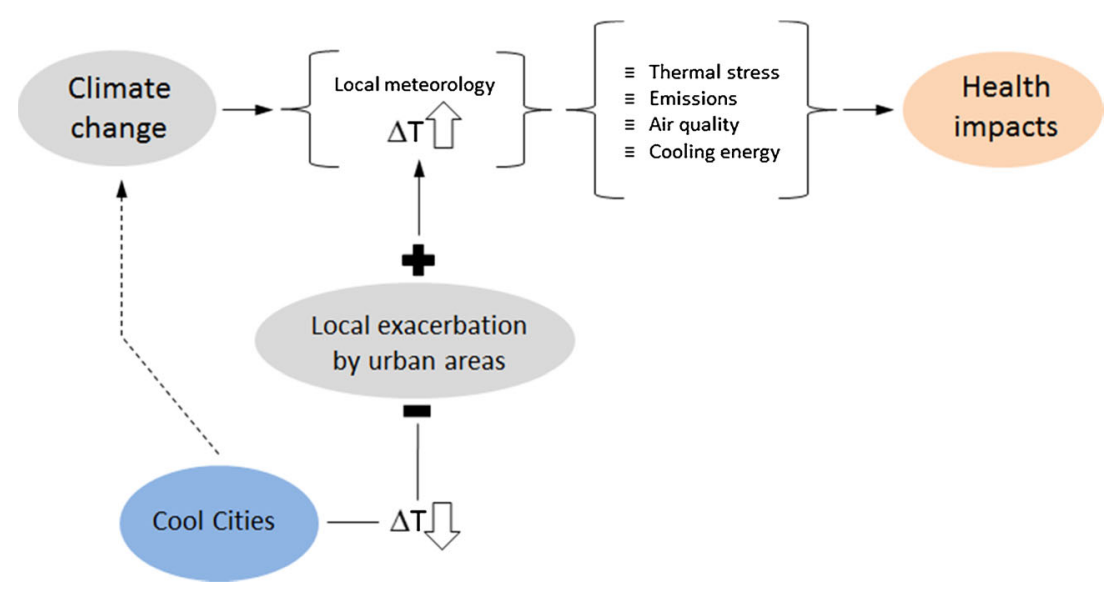


Table 1 Cool cities measures

\begin{tabular}{|c|c|c|}
\hline Measure & Health-relevant pathways & \\
\hline \multirow[t]{2}{*}{ Cool roofs } & $\begin{array}{l}\text { - Decreased surface, air, and apparent temperatures } \\
\text { - Decreased anthropogenic and biogenic emissions }\end{array}$ & \multirow[t]{2}{*}[11,17\bullet,18,19]{} \\
\hline & - Reduced photochemical reaction rates & \\
\hline \multirow[t]{2}{*}{ Cool pavements } & $\begin{array}{l}\text { - Decreased surface }{ }^{\text {a }} \text {, air, and apparent temperatures } \\
\text { - Decreased anthropogenic and biogenic emissions }\end{array}$ & \multirow[t]{2}{*}{$\begin{array}{l}{[11,17 \bullet, 18,20 \bullet} \\
\quad 21,22]\end{array}$} \\
\hline & - Reduced photochemical reaction rates & \\
\hline \multirow[t]{3}{*}{ Urban forests } & $\begin{array}{l}\text { - Increased deposition of pollutants } \\
\text { - Increased cooling (evapotranspiration }{ }^{\mathrm{b}} \text { ) and shading }\end{array}$ & \multirow[t]{3}{*}[23-26]{} \\
\hline & - Decreased anthropogenic and biogenic emissions & \\
\hline & - Reduced photochemical reaction rates ${ }^{\mathrm{c}}$ & \\
\hline Solar photovoltaics & $\begin{array}{l}\text { - Increased effective albedo }{ }^{\mathrm{d}} \\
\text { - Decreased surface, air, and apparent temperatures }\end{array}$ & {$[27]$} \\
\hline Green roofs/walls & - Decreased surface, air, and radiant temperatures & {$[25,28,29]$} \\
\hline \multirow[t]{2}{*}{ Anthropogenic-heating control } & $\begin{array}{l}\text { - Decreased air and apparent temperatures } \\
\text { - Decreased anthropogenic emission rates }\end{array}$ & \multirow[t]{2}{*}[30,31]{} \\
\hline & - Reduced photochemical reaction rates & \\
\hline \multirow[t]{2}{*}{ Runoff/surface-water control } & $\begin{array}{l}\text { - Decreased air temperature } \\
\text { - Decreased anthropogenic and biogenic emissions }\end{array}$ & \multirow[t]{2}{*}[32-34]{} \\
\hline & - Reduced photochemical reaction rates & \\
\hline
\end{tabular}

decreases in ozone depending on the local ratios of precursor concentrations. In another study of California [37•], it was found that cool roofs implemented per state regulations for commercial buildings will cause mean radiative forcing of $-1.38 \mathrm{~W} \mathrm{~m}^{-2}$ per 0.01 increase in albedo.

To date, there have been no observational studies of large urban areas or regions actually implementing cool cities measures, i.e., where surface modifications have been carried out intentionally for this purpose on a large scale. However, there exist limited observational data that could provide some realworld indications to the potential large-scale effects of the proposed measures. For example, an observational study [38] in White Sands National Monument $\left(\sim 400 \mathrm{~km}^{2}\right)$ in New Mexico showed that air temperature over the sandy areas (albedo $\sim 0.55$ ) can be up to $6^{\circ} \mathrm{C}$ lower than surrounding areas (albedo $\sim 0.20$ ) with $-2{ }^{\circ} \mathrm{C}$ being a more representative observed difference. An observational study in Spain [39] has documented negative radiative forcing and a cooling trend $\left(-0.3{ }^{\circ} \mathrm{C}\right.$ decade $\left.{ }^{-1}\right)$ because of land conversion into greenhouse farming over an area of $\sim 260 \mathrm{~km}^{2}$ (with an annual mean albedo that is 0.09 higher than over the surroundings).

\section{Global Scale}

At the global scale, a study [40] estimates that increasing albedo by 0.1 in major urban areas worldwide would decrease the global average temperature by $0.008{ }^{\circ} \mathrm{C}$ during the boreal summer. A similar effort [41 - ] found that deployment of cool roofs and pavements throughout urban areas in the USA can cause the domain-wide annual average outgoing radiation to increase by $0.16 \pm 0.03 \mathrm{~W} \mathrm{~m}^{-2}$ and afternoon summertime urban air temperatures to decrease by $0.11-0.53{ }^{\circ} \mathrm{C}$. Some rural locations could warm up $\left(\sim 0.27^{\circ} \mathrm{C}\right)$ because of reduced cloud cover.

Another study [42] finds positive (cooling) effects from global implementation of cool roofs. Averaged over all urban areas, the annual mean heat island is decreased by $33 \%$ (from 1.2 to $0.8{ }^{\circ} \mathrm{C}$ ) and the daily urban maximum temperature reduced by $0.6{ }^{\circ} \mathrm{C}$. The daily minimum temperature is lowered by $0.3{ }^{\circ} \mathrm{C}$. On the other hand, a global modeling study [43 ${ }^{2}$ found that while urban albedo increase can result in urban-specific cooling (an average of $0.02{ }^{\circ} \mathrm{C}$ ), the global temperature can increase by $0.07{ }^{\circ} \mathrm{C}$.

However, these global studies did not account for other potentially beneficial effects of cool cities, such as the impacts on energy use, emissions, and chemistry. Thus, again, the implications of these and similar findings are that cool cities measures must be optimized specifically to each region and are not "one-size-fits-all" measures. 


\section{Health Implications}

For heat, the impacts of cool cities can be quantified via (1) changes in meteorological variables, (2) changes in heat indices, and (3) modifications to local air mass classification. At the synoptic scale, an air mass classification system was established to characterize heat health impacts and mortality $[44,45]$. Of 8 spatial synoptic categories in the system, the hot and humid Moist Tropical (MT+, MT++) and hot Dry Tropical (DT) air masses cause the most increase in mortality [44]. Thus from this perspective, one goal of cool cities is to decrease the occurrences and/or durations of these oppressive weather types. Indeed, a few studies suggest that cool cities can impart effects that are significant enough to shift the local air mass types to more benign ones $[46,47]$.

At the local scale, several indicators can be used to translate the effects of urban heat and its potential exacerbation of background climate effects and, by same token, the potential of cool cities in locally mitigating these effects. Excess mortality $(M)$ due to heat can be estimated as $[48,49 \cdot]$ :

$M=c_{1}+c_{2} D+c_{3} t+c_{4} T$

where $D$ is day sequence during an offensive weather type, $t$ is time of season, and $T$ is afternoon air or apparent temperature. The constants $c_{1}$ through $c_{4}$ are city- and air-mass-typespecific.

Generally, cool cities measures tend to affect (reduce) daytime more than nighttime temperatures $[11,18,36]$ and can thus help reduce mortality, since $T$ (in Eq. 1) is an afternoon temperature. ${ }^{1}$ While the daytime effects sometimes carry over to nighttime temperatures, daytime cooling is generally larger than at night for measures that involve modifying surface albedo. Several modeling studies of increased urban albedo indicate significant daytime cooling but smaller changes in nighttime air temperature $[11,17 \cdot, 18,42]$.

On the other hand, the impacts of vegetation-cover increase can differ from one situation to another. For example, one study shows that nighttime cooling $\left(0.7-2.8^{\circ} \mathrm{C}\right)$ from an urban park in Athens can be larger than daytime cooling [24] whereas a U.S. study shows some urban parks to be up to $7^{\circ} \mathrm{C}$ cooler than surrounding urban areas at night but only about $3{ }^{\circ} \mathrm{C}$ cooler during the day [50]. In other situations, vegetation canopies can be warmer at night [51] because of the smaller sky-view factor than in surroundings. This highlights the need for region and site specificity in developing cool cities measures to maximize the heat health benefits. For example, at the regional scales, drier climates generally favor both urban forest and albedo control measures, whereas relatively more humid climates favor reflective surfaces. Variations in microclimates within each region can further dictate the measures that

\footnotetext{
${ }^{1}$ Other formulations include both nighttime (0300 LST) and daytime (1700 LST) temperatures.
}

would be most effective, depending on available sunshine (cloudiness/fogginess), temperature, humidity, wind patterns, anthropogenic and biogenic emissions, soil moisture availability, urban morphological characteristics, technical potential for deployment of control measures, and other considerations. Based on these factors and on the indirect atmospheric impacts of mitigation techniques, it is possible to prioritize and rank the measures in Table 1 per site- region-specific characteristics $[20 \bullet, 52]$.

In terms of air quality, ${ }^{2}$ there are similarly several ways to evaluate the potential health impacts. These include (1) evaluation of changes in concentrations, (2) changes relative to established thresholds and standards, and (3) changes in the air quality index (AQI). In "Air Quality" section, examples are provided.

A number of studies have evaluated the impacts of ozone on health and mortality. One study analyzed impacts in 95 U.S. urban areas and found a $0.25 \%$ increase in mortality for each $10 \mathrm{ppb}$ increase in 24-h average ozone (1-day lag) [53]. It was also found that mortality ranges from 0.52 to $0.64 \%$ per $10 \mathrm{ppb}$ increases in prior-week ozone concentrations (1-week lag). Another study found an increase in mortality risk of $0.8 \%$ per $10 \mathrm{ppb}$ increase in ozone [54]. For longterm exposure, the relative risk of mortality from respiratory causes was found to be 1.040 for each $10 \mathrm{ppb}$ increase in ozone [55].

An aspect of interest is whether air quality and heat should be evaluated separately or as confounding factors [56]. This is of relevance to cool cities because urban cooling affects meteorology (heat), emissions (air quality), and chemistry (air quality) simultaneously and, thus, quantifying health benefits would be more realistic, and possibly larger, if heat and air quality impacts are accounted for simultaneously. A review [57] found mixed results in terms of air pollution $\left(\mathrm{O}_{3}, \mathrm{PM}_{10}\right.$, $\mathrm{PM}_{2.5}, \mathrm{CO}, \mathrm{NO}_{2}$, and $\mathrm{SO}_{2}$ ) as a confounder or modifier to heat-mortality associations. Some studies found no confounding effects whereas others suggested impacts from $\mathrm{PM}_{10}$ and $\mathrm{O}_{3}$.

In a study of the heat discomfort index (DI) and air quality index (AQI) under heat-wave and non-heat-wave conditions, it was found that the two indices correlated during hot conditions [58]. Similarly, researchers in a Mediterranean climate found that when the common air quality index exceeded 76, the DI was highest [59].

The compounding effects of air pollution on heat stress during different weather types were evaluated in 12 Canadian cities [48]. It was found that within air mass types DT and $\mathrm{MT}+[45,46]$ there was a 4-fold and 2-fold increase,

\footnotetext{
${ }^{2}$ Climate change, UHI, and their mitigation affect many pollutants. The focus in this paper is on ozone because most studies of cool cities to date have evaluated this pollutant and health studies show that ozone and particulate matter are the most influential.
} 
respectively, in likelihood of extreme pollution events. ${ }^{3}$ It was also found that single-pollutant impacts on mortality depended on the air mass type. For example, the average pollutant-induced increases in mortality within DT and MT+ weather types were respectively 14.9 and $11.9 \%$ higher than for other weather types. In Adelaide, Australia, a study developed temperature thresholds for heat while accounting for ozone and $\mathrm{PM}_{10}$. After adjusting for the effects of pollutants, it found a 6-fold increase in emergency department presentation per $10{ }^{\circ} \mathrm{C}$ increase in maximum air temperature [60].

\section{Impacts of Climate and Heat Islands}

\section{Heat}

Global temperatures, expected to rise $2-5^{\circ} \mathrm{C}$ by the end of the century [6], can be locally exacerbated by UHIs. To evaluate the synergistic interactions between climate and UHI, studies have examined the response in urban and non-urban temperatures to heat waves. In one study, observational data from Baltimore, MD, show that heat waves increase the UHI intensity because of low urban surface moisture and wind speeds [61•]. The data show that the 2008 heat wave increased the nighttime UHI from 0.5 to $2.5^{\circ} \mathrm{C}$ and the daytime UHI from 0.25 to $1.5^{\circ} \mathrm{C}$. Since such conditions could become more common under climate change, it can be expected that UHI intensities will increase in the future.

In a modeling study of several U.S. regions [9॰], it was found that urban temperatures would increase between 0.5 and $1.2{ }^{\circ} \mathrm{C}$ which is additional exacerbation to the background climate effect. In Houston, TX [62], the urban area could get $2{ }^{\circ} \mathrm{C}$ hotter because of changes in climate and land use. Another study [63] found that urbanization between 1993 and 2004 increased the daytime UHI by $0.6{ }^{\circ} \mathrm{C}$ and nighttime UHI by $1.4{ }^{\circ} \mathrm{C}$ in the Pearl River and Yangtze River delta regions in China. That study also showed an increase in UHI intensity over time. For example, in Shanghai, the UHI was found to increase by $0.025^{\circ} \mathrm{C}$ year ${ }^{-1}$. The urban exacerbation can also be seen in heat health impacts and mortality rates. A study of the 1998 heat wave in Shanghai [64] found that excess mortality was 27.3 per 100,000 in urban areas but only 7.0 per 100,000 in non-urban surroundings. These additional $\sim 20$ deaths per 100,000 are caused mainly by the UHI. Similarly, a study of Hong Kong [65] found that a $1{ }^{\circ} \mathrm{C}$ increase in background temperature above $29{ }^{\circ} \mathrm{C}$ caused $4.1 \%$ increase in mortality in areas within heat islands but only $0.7 \%$ increase in non-heat island areas, thus an urban contribution (exacerbation) of $3.4 \%$.

\footnotetext{
${ }_{3}^{3}$ Extreme pollution events are defined as occurrences of top $5 \%$ pollutant concentrations.
}

A study of Tokyo using the A1B scenario [66] suggests that temperature in 2070 will be $2{ }^{\circ} \mathrm{C}$ higher than in 1990. Urban exacerbation contributes $0.6^{\circ} \mathrm{C}$ to the current heat island of $1{ }^{\circ} \mathrm{C}$ - thus the study predicts a future UHI contribution of $1.6{ }^{\circ} \mathrm{C}$. In Israel, the difference in discomfort index between an urban area (Beer Sheva) and non-urban surrounds increases by $0.022-0.024$ years $^{-1}$ and the physiological equivalent air temperature (PET) increases by $0.048-0.063 \mathrm{C}^{\circ}$ years ${ }^{-1}$ due to urban exacerbation of the background climate effect on heat stress [67].

In a study of climate change impacts on Korean cities [46], conservative model scenarios for the city of Busan show that occurrences of DT weather type would increase from less than $1 \%$ in early twenty-first century to $3 \%$ by end of the century. The occurrences of MT++ would increase from $0.24 \%$ presently to $9.33 \%$ by 2090 . Conversely, there may be regions where the UHI could decrease with climate change. For example, Paris, France, under scenarios A1B and A2 could warm up slower than its non-urban surrounds because of the latter's lower soil moisture [68]. Furthermore, the study suggests larger reductions in the nighttime UHI than in daytime UHI.

Thus, the magnitudes and tendencies of the UHI in a changing climate will depend on the differences in thermophysical properties of urban areas relative to those of their non-urban surroundings. However, in terms of mitigation, it is expected that urban cooling will be equally effective regardless of whether UHIs increase or decrease in the future.

\section{Air Quality}

Many studies have evaluated the future air quality implications of a changing climate including or separately from the effects of emission controls. Findings suggest that the local effects of climate change can in some cases offset the benefits of planned emission-reduction measures [69, 70]. Hence, from this perspective, cool cities can help offset the urbanization and local climate effects on meteorology and provide benefits in parallel to traditional emission-control strategies.

Climate change will worsen air quality by (1) increasing emissions, (2) increasing production of ozone, and (3) lengthening the ozone season and poor air quality episodes. A study of the USA [71] projects an increase of $2-15 \mathrm{ppb}$ in the maximum 8-h average ozone by 2050 due to climate change (A1B scenario). It is also likely that by the end of the century, stagnation events will become more frequent. Using an air stagnation index, a study [72] projects an increase of up to 40 days per year with stagnation events by the late twenty-first century in the tropics and sub-tropics as well as some mid-latitude regions.

In European suburban areas, climate change could cause an increase in ozone such that the annual mean and average daily ozone maxima are increased by up to $1.5 \mathrm{ppb}$, and the number 
of high ozone days increased by 5-30\% [73]. In China [63], a study showed that the meteorological consequences of urbanization between 1993 and 2004, i.e., the UHI, increased ground level ozone by 4.7-8.5\% at night and 2.9-4.2\% during the day. Other studies indicate that climate change will cause an increase of $1-10 \mathrm{ppb}$ in ozone in urban areas driven mainly by higher temperatures (UHI), whereas background ozone might decrease somewhat because of increased water vapor [74].

Fine-resolution meteorological, emissions, and photochemical modeling of downscaled IPCC scenarios for California found that the $1-\mathrm{h}$ peak ozone concentrations can increase by up to $11 \mathrm{ppb}$ in the Los Angeles Basin and $9 \mathrm{ppb}$ in the Sacramento Valley by 2090 assuming controlled emissions (meaning future emission controls are in place) [70]. The study also found that the correlation between changes in ozone and temperature is (1) $0.67 \mathrm{ppb}{ }^{\circ} \mathrm{C}^{-1}$ for peak ozone at times and locations of present-day peaks, (2) $4.61 \mathrm{ppb}{ }^{\circ} \mathrm{C}^{-1}$ for the largest increase anytime anywhere in the domain, and (3) $8-10 \mathrm{ppb}^{\circ} \mathrm{C}^{-1}$ (up to $15 \mathrm{ppb}{ }^{\circ} \mathrm{C}^{-1}$ ) for the largest ozone increase anywhere any time in the domain but with uncontrolled emissions [70]. In Houston, TX, a modeling study [62] evaluated the A1B scenario and found that the impacts of climate change alone would be to increase ground level 8-h maximum ozone by $2.6 \mathrm{ppb}$. When urbanization effects are also accounted for, the increase in the 8-h maximum reaches up to $6.2 \mathrm{ppb}$.

Another study [75] indicated a range of effects from climate change including increased ozone production of 2$15 \mathrm{ppb}{ }^{\circ} \mathrm{C}^{-1}$, similar in magnitude to the results above [70]. Analysis by the U.S. EPA [76] suggests that climate change will increase summer-time average ozone by $2-8$ ppb in many regions and also lengthen the ozone season.

\section{Potential of Cool Cities to Counteract Urban and Climate Change Effects}

In this section, the potential impacts of cool cities on health are discussed (1) in terms of changes in variables of relevance to heat and/or air quality, (2) modifications to heat and/or air quality metrics relative to thresholds or standards, and (3) modifications to classification of health impacts. This is summarized in Table 2 which is expanded into BOX H1 through $\mathrm{H} 3$ for heat and BOX AQ1 through AQ3 for air quality. Each box shows the changes in the indicator (column 1), a description of the changes (column 2), the cool cities measures causing the changes (column 3), and references (column 4). The effects are for cool roofs (CR), cool pavements (CP), urban forestation (UF), conversion of impervious to pervious surfaces and runoff control (IM/P), vegetation and/or structural shade (V/S), and green roofs (GR).
The amount of cooling achievable with these measures is strongly dependent on (1) the size of the urban area to be modified, (2) deployment and technical potentials in each area, as well as (3) the local climate characteristics [11, 17•, 18, $20 \bullet$. Results presented below and in "Conclusions" section show that, in general, the magnitudes of effects from cool cities are significant and sufficiently large to mitigate the effects of heat islands and locally offset some of the effects of climate change on heat and/or air quality health.

\section{Heat Health}

Several formulations of the heat index have been developed to translate environmental conditions into quantifiable health metrics [83]. One of the more commonly used indexes is that of the National Weather Service (NWS) [83, 84]. More recent formulations include the Universal Thermal Climate Index (UTCI) which is an equivalent-temperature model that also includes clothing and adaptation models of the urban population [85].

Taking the commonly-used NWS heat index $(H I)$ and partially differentiating with respect to temperature $(T)$, we obtain:

$$
\frac{\partial H I}{\partial T}=c_{2}-c_{4} H-2 c_{5} T+2 c_{7} T H+c_{8} H^{2}-2 c_{9} T H^{2}
$$

where $c_{2}=2.04901, c_{4}=0.224755, c_{5}=0.006837, c_{7}=$ $0.001228, c_{8}=0.000852$, and $c_{9}=0.00000199$, and where $H I$ and $T$ are in degree ${ }^{\circ} \mathrm{F}$, and $H$ (relative humidity) is in percent. At the milder end of a heat event, for example, $85{ }^{\circ} \mathrm{F}\left(29.4{ }^{\circ} \mathrm{C}\right)$ and $40 \%$ relative humidity, $\partial H I / \partial T$ from Eq. 2 is $1.06{ }^{\circ} \mathrm{F}{ }^{\circ} \mathrm{F}^{-1}\left(1.9{ }^{\circ} \mathrm{F}{ }^{\circ} \mathrm{C}^{-1}\right)$ whereas during a relatively more severe event, say $94^{\circ} \mathrm{F}$ $\left(34.4{ }^{\circ} \mathrm{C}\right.$ ) and $70 \%$ relative humidity, $\partial H I / \partial T$ is $3.53{ }^{\circ} \mathrm{F}^{\circ} \mathrm{F}^{-1}\left(6.4{ }^{\circ} \mathrm{F}{ }^{\circ} \mathrm{C}^{-1}\right)$. Considering that cooling of $1-3{ }^{\circ} \mathrm{C}$ is achievable with cool cities (see column 1 in BOX H1), the reductions in $H I$ can amount to up to $19{ }^{\circ} \mathrm{F}\left(10.6^{\circ} \mathrm{C}\right)$ in the relatively more severe event. This is comparable to $\mathrm{BOX} \mathrm{H} 2$ where the heat index ranges from 3.5 to $10{ }^{\circ} \mathrm{C}$. Even if cool cities achieved only a $0.5-1{ }^{\circ} \mathrm{C}$ reduction in air temperature (e.g., some of the lower values in BOX H1), the effects will still be significant, e.g., $1.9-6.4{ }^{\circ} \mathrm{F}\left(1-3.6{ }^{\circ} \mathrm{C}\right)$ and, in some cases, can shift the local air mass classification to a less severe one, as seen in BOX H3, for example.

In a study of increased urban albedo $(+0.1)$ and vegetation cover $(+10 \%)$ [47], it was found that in Baltimore, Los Angeles, and New York, the average change in air temperature is $-0.5,-0.7$, and $-0.2{ }^{\circ} \mathrm{C}$, respectively, with an increase of between 0.1 and $0.3^{\circ} \mathrm{C}$ in dew point temperature for the case with vegetation cover modification. The corresponding effects on health are reductions in mortality of 2,1 , and $9 \%$, 
Table 2 Framework for discussion of cool cities impacts

Changes in relevant variables:

Heat
Air quality
Change
BOX $\mathrm{H} 1$
$0.11-0.53{ }^{\circ} \mathrm{C} \mathrm{T}_{\text {air }} \downarrow$
$2.00-3.75{ }^{\circ} \mathrm{C} \mathrm{T}_{\text {air }} \downarrow$
$1.50-2.00{ }^{\circ} \mathrm{C} \mathrm{T}_{\text {air }} \downarrow$
$0.30-0.50{ }^{\circ} \mathrm{C} \mathrm{T}_{\text {air }} \downarrow$
$1.00-4.00{ }^{\circ} \mathrm{C} \mathrm{T}_{\text {air }} \downarrow$
$0.20-2.60{ }^{\circ} \mathrm{C} \mathrm{T}_{\text {air }} \downarrow$
$2.5{ }^{\circ} \mathrm{C} \mathrm{T}_{\text {air }} \downarrow$
$2.0{ }^{\circ} \mathrm{C} \mathrm{T}_{\text {air }} \downarrow$
$0.8-2.0{ }^{\circ} \mathrm{C} \mathrm{T}_{\text {air }} \downarrow$
$3-6$ dh day ${ }^{-1} \downarrow$
$6-7 \mathrm{dh}$ day ${ }^{-1} \downarrow$

BOX H2

UTCI $10{ }^{\circ} \mathrm{C} \downarrow$

HI $4.3^{\circ} \mathrm{C} \downarrow$

UTCI $3.5^{\circ} \mathrm{C} \downarrow$

UTCI $4.3^{\circ} \mathrm{C} \downarrow$

BOX H3

UTCI "moderate-strong" to "no stress-moderate"

Air mass $\mathrm{MT}++$ to $\mathrm{MT}+$ or

DT to either DM or MT

\section{BOX AQ1}

66-185 mtpd VOC $\downarrow$ (3-9 \%)

51-77 mtpd VOC $\downarrow(5-8 \%)$

5-10 ppb [O3] $\downarrow$

BOX AQ2

$5.5 \mathrm{ppb}\left[\mathrm{O}_{3}\right] \downarrow$

$3.5 \mathrm{ppb}\left[\mathrm{O}_{3}\right] \downarrow$

$2.4 \mathrm{ppb}\left[\mathrm{O}_{3}\right] \downarrow$
- Air temperature

- Apparent temperature ${ }^{\mathrm{a}}$

- Degree-hours

BOX H1

- Concentrations

- Population weighted exceedance

- Emissions

- Emission equivalents

BOX AQ1

Notes

Summer afternoon average over several U.S. urban areas (continental scale)

Maximum daytime decrease, Southern California, USA (mesoscale)

Maximum daytime decrease San FranciscoSacramento region, USA (mesoscale)

Average daytime air temperature, Philadelphia, USA

Nighttime heat-island reduction, London, UK

Urban forest/park daytime cooling (UCI), Athens, Greece

Peak daytime air temperature, Atlanta, USA

Largest reduction in UHI, Stuttgart Germany

Range of largest changes for several U.S. urban regions

Relative to $15{ }^{\circ} \mathrm{C}$, range of average over monitor locations in central California, USA

Relative to $15{ }^{\circ} \mathrm{C}$, range of average over monitor locations in southern California, USA

From average UTCI 33 to $23{ }^{\circ} \mathrm{C}$, shading, Canada and Korea

Imperviousness 71.9 to $12.8 \%$, Florence, Italy

Evaporation from urban surfaces, summer, Zurich, Switzerland

Albedo increase, summer, Zurich, Switzerland

Heat stress, shading, Canada and Korea (microscale)

Several U.S. cities

Anthropogenic emission equivalents of increased albedo, Central California, USA

Anthropogenic emission equivalents of increased albedo, Los Angeles, USA

Representative changes in 1-h and 8-h average ozone, California urban areas, USA

Daily 1-h average maximum ozone, several urban areas, Southern California, USA

Daily 8-h average maximum ozone, several urban areas, Southern California, USA

Peak daylight ozone decrease, Washington DC-Massachusetts, USA
Changes in relevant metrics:

- Heat index value

BOX H2

-1-h average

- 8-h average

- AQI value

BOX AQ2

BOX AQ3

Measure

$\mathrm{CR}+\mathrm{CP}$

$\mathrm{CR}+\mathrm{CP}+\mathrm{UF}$

$\mathrm{CR}+\mathrm{CP}+\mathrm{UF}$

$\mathrm{CR}+\mathrm{CP}$

UF

UF

$\mathrm{CR}+\mathrm{CP}$

CR

$\mathrm{CR}+\mathrm{GR}$

$\mathrm{CR}+\mathrm{CP}$

$\mathrm{CR}+\mathrm{CP}$

V/S

IM/P

$\mathrm{CP}+\mathrm{CR}$

UF/shade

$\mathrm{CR}+\mathrm{CP}+\mathrm{UF}$

$\mathrm{CR}+\mathrm{CP}$

$[20 \bullet, 36]$

$\mathrm{CR}+\mathrm{CP}$

$[20 \bullet, 36]$

$\mathrm{CR}+\mathrm{CP}$

$[11,36]$

$\mathrm{CR}+\mathrm{CP}+\mathrm{UF}$

$\mathrm{CR}+\mathrm{CP}+\mathrm{UF}$

UF 
Table 2 (continued)

\begin{tabular}{|c|c|c|c|}
\hline & Changes in relevant variables: & $\begin{array}{l}\text { Changes in relevant } \\
\text { metrics: }\end{array}$ & $\begin{array}{l}\text { Changes in class or } \\
\text { category: }\end{array}$ \\
\hline $12.0 \mathrm{ppb}\left[\mathrm{O}_{3}\right] \downarrow$ & $\begin{array}{l}\text { Average changes in 1-h peak, San Francisco- } \\
\text { Sacramento, USA }\end{array}$ & $\mathrm{CR}+\mathrm{CP}+\mathrm{UF}$ & [18] \\
\hline $1-5 \mathrm{ppb}\left[\mathrm{O}_{3}\right] \downarrow$ & $\begin{array}{l}\text { 1-h peak, multi-seasonal range, urban areas in } \\
\text { California, USA }\end{array}$ & $\mathrm{CR}+\mathrm{CP}$ & {$[20 \bullet$} \\
\hline $13 \%\left[\mathrm{O}_{3}\right] \downarrow$ & Maximum 8-h average, Sacramento, USA & $\mathrm{CR}+\mathrm{CP}$ & {$[11]$} \\
\hline $1 \%\left[\mathrm{O}_{3}\right] \downarrow$ & Average 8-h, Washington DC-Massachusetts, USA & UF & {$[82]$} \\
\hline \multicolumn{4}{|l|}{ BOX AQ3 } \\
\hline $\begin{array}{l}\text { "Very unhealthy" to } \\
\text { "unhealthy" }\end{array}$ & $\begin{array}{l}\text { Daily 8-h maximum ozone, several urban areas, } \\
\text { Southern California, USA }\end{array}$ & $\mathrm{CR}+\mathrm{CP}$ & {$[36]$} \\
\hline $\begin{array}{l}\text { "Unhealthy" to "unhealthy } \\
\text { for sensitive population" }\end{array}$ & $\begin{array}{l}\text { Daily 8-h maximum ozone, several urban areas, } \\
\text { Central and Southern California, USA }\end{array}$ & $\mathrm{CR}+\mathrm{CP}$ & {$[36]$} \\
\hline
\end{tabular}

$C R$ cool roofs, $C P$ cool pavements, $U F$ urban forest, $P V$ solar photovoltaic, $G R$ green roofs, $G W$ green walls, $Q F$ anthropogenic heat control, $I M / P$ runoff and soil moisture control, $V / S$ vegetation or structural shading, $A Q I$ air quality index, $H I$ heat index, UTCI universal thermal climate index (www.utci. org) [76], $T_{\text {air }}$ air temperature, $d h d a y^{-1}$ degree-hours per day, $m t p d$ metric tons per day, $p p b$ parts per billion

${ }^{\mathrm{a}}$ To also account for effects of relative humidity, wind speed, and solar radiation

respectively. A related study [49•] showed that for the District of Columbia, a 0.1 increase in urban albedo could reduce mortality by an average of $6 \%$ during excessive heat events.

In New York City, urban greening (converting impervious surfaces to tree canopies) can decrease air temperatures by an average of $1.9^{\circ} \mathrm{C}$ and up to $4.8^{\circ} \mathrm{C}$ [25]. A study of the USA [9•] suggests that implementation of green and reflective roofs can reduce air temperature in urban areas by $1.5-2{ }^{\circ} \mathrm{C}$. The study estimates that whereas future urban expansion in the USA could contribute $1-2{ }^{\circ} \mathrm{C}$ to the regional climate, cool cities could locally offset that warming.

A fine-resolution meso-urban modeling study of increasing urban albedo in the Sacramento Valley found a decrease in air temperature of up to $2-3{ }^{\circ} \mathrm{C}$ [11] for an increase in albedo of up to 0.4 on roofs and 0.15 on pavements. Another study [12] found that cool cities measures in Canada could reduce urban air temperatures by $0.5-1{ }^{\circ} \mathrm{C}$ (with highs as large as $3{ }^{\circ} \mathrm{C}$ possible). In the city of Stuttgart, Germany, the implementation of reflective roofs can decrease the heat island by up to $2{ }^{\circ} \mathrm{C}[79]$. A review of studies evaluating the effects of reflective surfaces on air temperature reports an average decrease of $0.3{ }^{\circ} \mathrm{C}$ for an increase of 0.1 in albedo of urban areas around the world [17•]. If only cool roofs were considered, the mean decrease in average urban air temperature would be $0.2{ }^{\circ} \mathrm{C}$. The review also reports an average decrease in peak temperatures of $0.9^{\circ} \mathrm{C}$ across several studies and regions.

A study of Atlanta, Philadelphia, and Phoenix estimates that by 2050 , heat-related mortality could be decreased by $40-99 \%$ if increased vegetation cover and surface albedo were implemented [86]. The study concluded that cool cities could help in adaptation to a changing climate. An analysis of the 2002 Beijing heat wave estimated that air temperature could be reduced by
$1.4{ }^{\circ} \mathrm{C}$ on the peak day of the heat event (an offset of $\sim 59 \%$ [ [87]. In the city of Melbourne, Australia, researchers suggest that urban forestation can help reduce average summer temperatures by up to $2{ }^{\circ} \mathrm{C}$ [88]. They also suggest that doubling vegetation cover in the city would reduce heat-related mortality by $5-28 \%$.

The foregoing discussion and the information in BOX H1-H3 show that cool cities can have a significant beneficial impact on temperature (H1), heat index (H2), and even weather type (H3).

\section{Air Quality Health}

Air quality health benefits from cool cities are achieved by (1) reducing emissions, (2) reducing emission equivalents, and (3) slowing photochemical production of ozone:

- Reduced emissions result from (1) reduction in power generation because of direct (building) and indirect (atmospheric) effects on cooling energy demand, (2) reduction in temperature-dependent biogenic and anthropogenic emissions, and (3) reduction in fugitive/evaporative emissions [18];

- Emission equivalents represent the anthropogenic VOC and/or NOx emission reductions (or avoided emissions) that produce ozone reductions equal to those from cool cities impacts on atmospheric chemistry $[20 \bullet, 36]$, for example, BOX AQ1; and

- Slower photochemical production of ozone results from (1) smaller temperature-dependent reaction rates and (2) PAN chemistry (reduction of $\mathrm{NO}_{2}$ pool) $[11,18]$, as in BOX AQ2. 
The U.S. EPA's air quality index $(A Q I)$ is often used in operational forecasting for ozone (e.g., [89]). Differentiating $A Q I$ with respect to pollutant concentrations within the $A Q I$ range of 51-200 and using ozone as example, we obtain:

$\frac{\partial \mathrm{AQI}}{\partial c_{i}}=\frac{\mathrm{AQI}_{1}-\mathrm{AQI}_{2}}{\mathrm{bP}_{1}-\mathrm{bP}_{2}}=2.57 \mathrm{ppb}^{-1}$

where $c_{i}$ is the 8 -h concentration of ozone and $b P_{1}$ and $b P_{2}$ are the concentration break points corresponding to $A Q I_{1}$ and $A Q I_{2}$, respectively. Thus a change of $1 \mathrm{ppb}$ in the 8 -h averaged (maximum) ozone is equivalent to an $A Q I$ change of 2.57 points. Considering that ozone concentration decreases of 3$5 \mathrm{ppb}$ in 8-h averages are realistically possible with cool cities $[11,36]$, as also suggested in BOX AQ2, the $A Q I$ could be reduced by up to $8-13$ points, which is significant. In some cases, as shown in BOX AQ3, the reductions in ozone concentrations from cool cities can shift the $A Q I$ class altogether to a more benign one.

A fine-resolution urban meteorological and photochemical modeling study shows that in Sacramento, CA, ozone can be decreased by 5-11 ppb (1-h average) during the daytime as a result of increased surface albedo [11]. These decreases correspond to 2-4.5 $\mathrm{ppb}^{\circ} \mathrm{C}^{-1}$. Compared with the effects of climate change of $0.67-10 \mathrm{ppb}^{\circ} \mathrm{C}^{-1}$ [70] and $2-15 \mathrm{ppb}^{\circ} \mathrm{C}^{-1}$ [75], this would suggest that cool cities can offset about 30$50 \%$ of the local climate impacts in Sacramento. In terms of the daily maximum 8 -h average, the relative reduction factor (RRF) corresponding to these increases in albedo ranges from 4 to $9 \%[11,36]$. Since, as discussed earlier, an increase of $10 \mathrm{ppb}$ in ozone would result in an increase in mortality of $0.8 \%$ [52], the above reductions of 5-11 ppb from cool cities [11] would be roughly equivalent to a reduction of $0.8 \%$ in mortality.

In central California, the maximum 8-h ozone can be decreased by $1-2 \%$ and in southern California by $2-3.6 \%$ as a result of cool cities (increased urban albedo) [20•,36], which is comparable to other results, e.g., BOX AQ2. This can also shift the AQI from one class to another, as discussed above. In terms of urban greening, a study estimates decreases of up to $2.4 \mathrm{ppb}$ in daytime ozone concentrations as a result of urban forestation in northeastern USA [82]. However, the nighttime ozone can increase because of reduced mixing and non-urban areas can also experience an increase $(\sim 0.25 \mathrm{ppb})$ during the daytime. In another modeling study [12], it was shown that deployment of cool cities measures in Canada could reduce ozone by $2-4 \mathrm{ppb}$ (1-h average).

A multi-seasonal modeling evaluation of cool cities impacts on air quality found that in Central California, the 1-h peak ozone can be decreased by $1.2-5.2 \mathrm{ppb}[20 \cdot 36]$. Since cool cities can also cause increases in ozone, e.g., downwind of modified areas, the study [36] also evaluated the ratio of cumulative (ppb-hrs) decrease-to-increase (RDI) in ozone. It was found that RDI reaches up to 62 , an overwhelmingly positive effect. There was one episode out of 25 where the average RDI was about 1 . For Southern California, the study found that cool cities measures decrease the 1-h peak ozone by 4.8-8.4 ppb and that the RDI ranges from 19 to 99 (thus a larger impact than in Central California). These studies [18, $20 \bullet, 36]$ also show that heat island control can impact all regions, downwind included, in a beneficial way. In other words, upwind implementation of mitigation measures can also benefit those areas downwind regardless of whether or not mitigation measures are implemented in the downwind regions $[8,11,18]$.

In a study of regulatory episodes $[18,36]$, it was shown that the 1 -h peak ozone can be reduced by up to $16 \mathrm{ppb}$ as a result of deployment of cool cities measures in central California. Compared to $0.52-0.64 \%$ increase in mortality per $10 \mathrm{ppb}$ for 1 -week lag [53] discussed earlier, this yields a $0.83-1.02 \%$ reduction in mortality. The study [18] also shows that cool cities can reduce the 24-h average ozone in Southern California (averaged over urban regions) by up to $2 \mathrm{ppb}$. As discussed earlier [53], a $0.25 \%$ increase in mortality was estimated for each $10 \mathrm{ppb}$ increase in 24-h average (1-day lag). Thus the above 2-ppb decrease in the 24-h average from cool cities would translate into a decrease of $0.05 \%$ in mortality. If monitor-specific (not area-averaged) ozone changes were considered (which can reach up $8 \mathrm{ppb}$ ), the reductions in mortality risk will be dramatically larger (i.e., quadruple).

\section{Conclusions}

Results reviewed in this paper suggest that effects of cool cities are similar in magnitude (and opposite in direction) to those of UHI and/or local effects of climate change. While there are regional disparities in the magnitudes and sometimes even different directionalities, an overriding number of studies point to the conclusion that cool cities, if optimally deployed, have the potential to mitigate health effects of UHI and climate.

Figure 2 presents a sampling summary of such effects. The two ovals in the center equate the changes of $1{ }^{\circ} \mathrm{C}$ and $1 \mathrm{ppb}$ (ozone) to health as a basis for comparing the negative (above dashed line) and positive effects (below dashed line). The area of overlap between the ovals (darker pink) represents the combined effects of heat and air quality. The upper half of the figure depicts the negative effects of climate change and UHI on heat (grey) and ozone air quality (light pink). The bottom half shows the potential of cool cities in mitigating heat (blue) and air quality (green) effects. Areas of overlap (darker shades) represent the combined effects of reflective surfaces and vegetation measures $(\alpha+\eta)$. The cool cities examples in this figure are reflective roofs and increased canopy cover and the pollutant is ozone. 
Fig. 2 Sampling of magnitudes of heat and air quality impacts and mitigation potentials. Note 1: The numbers provided in parentheses (in the ovals) are the original form (as in the source/reference). Thus, linearity is assumed within the given range, which may or may not be a reasonable assumption. Note 2: The figure is for temperature and ozone and local effects only. The units "ppb" in the figure refer to ozone concentrations. Note 3: The arrows next to temperature or ozone changes indicate whether the variable is increasing $(\uparrow)$ or decreasing $(\downarrow)$. ${ }^{1}$ Various regions.

${ }^{2}$ Current UHI contributions

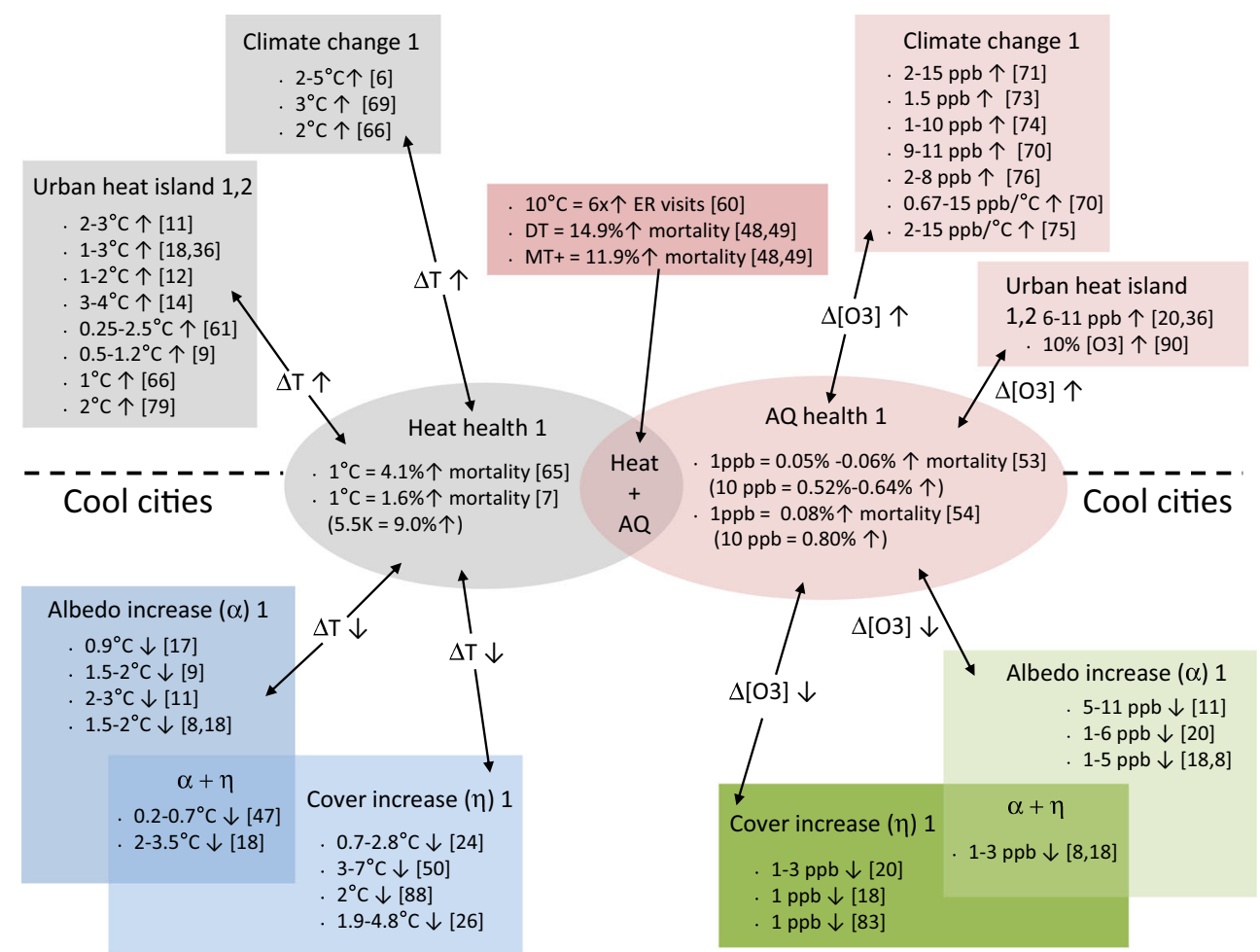

The figure depicts data from different regions and scenarios and, thus, is not intended as an exact one-to-one correspondence among the various variables and effects but, rather, a qualitative comparison of their magnitudes.

Figure 2 suggests that the magnitudes of climate change and UHI impacts on heat are more or less in the range of 1$5{ }^{\circ} \mathrm{C}$ and their localized effects on ozone in the range of $1-$ $15 \mathrm{ppb}$ (1-h averages). The counteracting effects of cool cities on heat are in the range of $1-4^{\circ} \mathrm{C}$ and on air quality, $1-11 \mathrm{ppb}$. This suggests that cool cities measures have the potential to locally offset most, if not all, of the local heat and air quality effects (ozone) of climate change and/or urban heat islands. This also suggests that the benefits of cool cities are significant enough, warranting further research to tailor the strategies for region specifics, maximize their local benefits, and minimize inadvertent effects.

Future efforts in optimizing the design and deployment of heat island control measures and analyzing their effects should also consider that the effectiveness of cool cities depends on geographical, microclimate, and regional weather characteristics as well as other physical properties, including size of urban areas, spatial characteristics, density of urbanization, and deployment potential for mitigation measures. The effectiveness of heat island control will also depend on interactions among the various measures (sometimes in a highly nonlinear manner) with both positive and negative net effects as possible outcomes from these processes. Thus, it is useful to prioritize and rank the measures based on their indirect impacts on the atmosphere and the consideration of all of these site-specific, local factors $[20 \bullet, 52]$. Furthermore, feedbacks from chemistry to meteorology, e.g., radiative forcing, should also be examined further. For example, heat island control measures that can reduce air pollutant concentrations, such as $\mathrm{NO}, \mathrm{NO}_{2}, \mathrm{VOC}, \mathrm{O}_{3}$, and PM directly (e.g., deposition in vegetation canopies or reduction in emissions) or indirectly (e.g., slowing photochemical production of ozone because of lowered air temperatures) can also affect heating or cooling of the atmosphere because of changes in radiative forcing that result from changes in concentrations of gases and PM [8, 18, 36, 91].

Finally, future research on the effects of cool materials should also distinguish between and quantify the different effects of ground-based increases in albedo (pavements, parking lots, etc.) and the elevated canopy- or boundary-layer effects of roof- or wall-based increases in albedo. Current modeling capabilities and recent urban parameterizations in atmospheric models allow for finescale vertical resolution and distinction between these effects (elevated versus coupled to the ground). This is important in developing mitigation measures that are tailored to local-scale and site-specific characteristics in addition to general regional properties.

Conflict of Interest The corresponding author states that there is no conflict of interest. 


\section{References}

Papers of particular interest, published recently, have been highlighted as:

- Of importance

1. Tebaldi C, Hayhoe K, Arblaster JM, Meehl GA. Going to the extremes: an intercomparison of model simulated historical and future changes in extreme events. Clim Chang. 2006;79:185-211.

2. Gershunov A, Douville H. In: Climate Extremes and Society, Diaz HF, Murnane RJ, editors. Extensive summer hot and cold extremes under current and possible future climatic conditions: Europe and North America. Cambridge: Cambridge University Press; 2008. p. 74-98.

3. Gershunov A, Cayan DR, Iacobellis SF. The Great 2006 heat wave over California and Nevada: signal of an increasing trend. J Clim. 2009;22:6181-203. doi:10.1175/2009JCLI2465.1.

4. World Meteorological Organization (WMO). International Meteorological Vocabulary, No. 182. 2015. http://www.wmo.int. Accessed 20 Dec 2014.

5. Petkova PE, Bader DA, Anderson GB, Horton RM, Knowlton K, Kinney PL. Heat-related mortality in a warming climate: projections for 12 U.S. cities. Int J Environ Res Public Health. 2014;11: 11371-83. doi:10.3390/ijerph111111371.

6. Intergovernmental Panel on Climate Change. The physical science basis. Contribution of Working Group I to the fifth assessment report of the intergovernmental panel on climate change. Cambridge: Cambridge University Press; 2013. 2216 p.

7. Ostro BD, Roth LA, Green RS, Basu R. Estimating the mortality effect of the July 2006 California heat wave. Environ Res. 2009;109:614-9.

8. Taha H. Urban surface modification as a potential ozone air-quality improvement strategy in California - Phase One: initial mesoscale modeling. Altostratus Inc. for the California Energy Commission, PIER Energy-Related Environmental Research, CEC-500-2005128. 2005. http://www.energy.ca.gov/2005publications/CEC-5002005-128/CEC-500-2005-128.PDF. Accessed 15 Jan 2015.

9. Georgescu M, Morefield PE, Bierwage BG, Weaver CP. Urban adaptation can roll back warming of emerging metropolitan regions. Proc Natl Acad Sci. 2014;111:2909-14. doi:10.1073/pnas. 1322280111. Provides indications that cool cities can mitigate the effects of future urbanization.

10. Zhou YZJ, Shepherd M. Atlanta's urban heat island under extreme heat conditions and potential mitigation strategies. Nat Hazards. 2010;52:639-68. doi:10.1007/s11069-009-9406-z. Evaluates the potenatial of cool cities in countering heat-wave conditions.

11. Taha H. Meso-urban meteorological and photochemical modeling of heat island mitigation. Atmos Environ. 2008;42:8795-809. doi: 10.1016/j.atmosenv.2008.06.036.

12. Taha H, Hammer H, Akbari H. Meteorological and air quality impacts of increased urban albedo and vegetative cover in the greater Toronto Area, Canada. Lawrence Berkeley National Laboratory Report LBNL-49210, Berkeley, California. 2002.

13. Lombardo MA. Ilhas de Calor nas Metrópoles: o exemplo de São Paulo. São Paulo: HUCITEC; 1985. 244 p.

14. Rajagopalan P, Lim KC, Jamei E. Urban heat island and wind flow characteristics of a tropical city. Sol Energy. 2014;107:159-70.

15. Garcia-Cueto OR, Jauregui-Ostos E, Toudert D, Tejeda-Martinez A. Detection of the urban heat island in Mexicali, B.C., México and its relationship with land use. Atmosfera. 2007;20:111-31.

16. Navigant Consulting Inc. Assessment of international heat island research. Report prepared for the U.S. Department of Energy. 2011. http://apps1.eere.energy.gov/buildings/publications. Accessed 10 Jan 2015.

17. Santamouris M. Cooling the cities - a review of reflective and green roof mitigation technologies to fight heat island and improve comfort in urban environments. Sol Energy. 2014;103:682-703. doi:10. 1016/j.solener.2012.07.003. Provides a good review of several studies on heat-island mitigation measures and their potential impacts.

18. Taha H. Urban surface modification as a potential ozone air-quality improvement strategy in California: a mesoscale modelling study. Bound-Layer Meteorol. 2008;127:219-39. doi:10.1007/s10546007-9259-5.

19. Ban-Weiss GA, Woods J, Levinson R. Using remote sensing to quantify albedo of roofs in seven California cities, Part 1: Methods. Sol Energy. 2015. doi:10.1016/j.solener.2014.10. 022. In Press.

20. Taha H. Meteorological, emissions and air-quality modeling of heat-island mitigation: recent findings for California, USA. Int J Low Carbon Technol. 2013; 0,-12 doi: 10.1093/ijlct/ctt010. An overview of selected cool-cities studies and potential impacts of deployment in California.

21. Pomerantz M, Akbari H, Chang S-C, Levinson R, Pon B. Examples of cooler reflective streets for urban heat-island mitigation: Portland cement concrete and chip-seals. Lawrence Berkeley National Laboratory, LBNL-49283. 2003

22. Carnielo E, Sinzi M. Optical and thermal characterization of cool asphalts to mitigate urban temperatures and building cooling demand. Build Environ. 2013;60:56-65. doi:10.1016/j.buildenv. 2012.11.004.

23. Taha H. Episodic performance and sensitivity of the urbanized MM5 (uMM5) to perturbations in surface properties in Houston TX. Bound-Layer Meteorol. 2008;127:193-218. doi:10.1007/ s10546-007-9258-6.

24. Skoulika F, Santamouris M, Kolokotsa D, Boemia N. On the thermal characteristics and the mitigation potential of a medium size urban park in Athens, Greece. Landsc Urban Plann. 2013;123:7386. doi:10.1016/j.landurbplan.2013.11.002.

25. Rosenzweig C, Solecki WD, Slosberg RB. Mitigating New York City's heat island with urban forestry, living roofs, and light surfaces. Report 06-06 (October 2006) New York City Regional Heat Island Initiative, prepared for New York State Energy Research and Development Authority; 2006.

26. Park S, Tuller SE, Jo M. Application of Universal Thermal Climate Index (UTCI) for microclimatic analysis in urban thermal environments. Landsc Urban Plan. 2014;125:146-55. doi:10.1016/j. landurbplan.2014.02.014.

27. Taha H. The potential for air-temperature impact from large-scale deployment of solar photovoltaic arrays in urban areas. Sol Energy. 2013;91:358-67. doi:10.1016/j.solener.2012.09.014.

28. Smith K, Roeber P. Green roof mitigation potential for a proxy future climate scenario in Chicago, Illinois. J Appl Meteorol Climatol. 2011;50:507-22.

29. Yang J, Wang Z-H. Physical parameterization and sensitivity of urban hydrological models: application to green roof systems. Build Environ. 2014;75:250-63. doi:10.1016/j. buildenv.2014.02.006

30. Taha H. Urban climates and heat islands: albedo, evapotranspiration, and anthropogenic heat. Energy Build Spec Issue Urban Heat Islands. 1997;25:99-103. doi:10.1016/S0378-7788(96)00999-1.

31. De Munck C, Pigeon G, Masson V, Meunier F, Sbousquet P, Tremeac B, et al. How much can air conditioning increase air temperatures for a city like Paris, France? Int J Climatol. 2013;33:210-27.

32. Massetti L, Petralli M, Brandani G, Orlandini S. An approach to evaluate the intra-urban thermal variability in summer using an 
urban indicator. Environ Pollut. 2014;192:259-65. doi:10.1016/j. envpol.2014.04.026.

33. Völker S, Baumeister H, Classen T, Hornberg C, Kistemann T. Evidence for the temperature mitigating capacity of urban blue space - a health geographic perspective. Erkunde. 2013;67:35571. doi:10.3112/erdkunde.2013.04.05.

34. Coutts AM, Tapper NJ, Beringer J, Loughnan M, Demuzere M. Watering our cities: the capacity for water sensitive urban design to support urban cooling and improve human thermal comfort in the Australian context. Prog Phys Geogr. 2012;37:2-28. doi:10.1177/ 0309133312461032

35. Rosenfeld AH, Akbari H, Romm JJ, Pomerantz M. Cool communities: strategies for heat island mitigation and smog reduction. Energy Buildings. 1998;28:51-62. doi:10.1016/S0378-7788(97) 00063-7.

36. Taha H. Multi-episodic meteorological, air-quality, and emissionequivalence impacts of heat-island control and evaluation of the potential atmospheric effects of urban solar PV arrays. Altostratus Inc. for the California Energy Commission, PIER Energy-Related Environmental Research. CEC-500-2013-061. www.energy.ca. gov/2013publications/CEC-500-2013-061/CEC-500-2013-061. pdf; 2011. Accessed 4 Feb 2015.

37. Van Curen R. The radiative forcing benefits of "cool roof" construction in California: quantifying the climate impacts of building albedo modification. Clim Chang. 2011;112:1071-83. doi:10.1007/ s10584-011-0250-2. An evaluation of the potential large-scale benefits from heat-island mitigation.

38. Fishman B, Taha H, Akbari H. Meso-scale cooling effects of high albedo surfaces: analysis of meteorological data from White Sands National Monument and White Sands Missile Range. Lawrence Berkeley National Laboratory Report LBNL-35056. 1994. http:// www.osti.gov/energycitations/servlets/purl/10180636-qtCaZE/ native/. Accessed 4 Feb 2015.

39. Campra P, Garcia M, Canton Y, Palacios-Orueta A. Surface temperature cooling trends and negative radiative forcing due to land use change toward greenhouse farming in southeastern Spain. J Geophys Res. 2008;113, D18109. doi:10.1029/ 2008JD009912.

40. Menon S, Akbari H, Mahanama S, Sednev I, Levinson R. Radiative forcing and temperature response to changes in urban albedos and associated CO2 offsets. Environ Res Lett. 2010;5:014005. doi:10. 1088/1748-9326/5/1/014005.

41. Millstein D, Menon S. Regional climate consequences of largescale cool roof and photovoltaic array deployment. Environ Res Lett. 2011;6:034001. doi:10.1088/1748-9326/6/3/034001. An evaluation of the potential global impacts of increased urban albedo.

42. Oleson KW, Bonan GB, Feddema J. Effects of white roofs on urban temperature in a global climate model. Geophys Res Lett. 2010;37, L03701. doi:10.1029/2009GL042194.

43. Jacobson MZ, Ten Hoeve JE. Effects of urban surfaces and white roofs on global and regional climate. J Clim. 2011;25:1028-44. doi: 10.1175/JCLI-D-11-00032.1. An evaluation of the potential global cooling and warming impacts of increased urban albedo.

44. Kalkstein LS, Greene S, Mills DM, Samenow J. An evaluation of the progress in reducing heat-related human mortality in major U.S. cities. Nat Hazards. 2010;56:113-29. doi:10.1007/s11069-0109552-3.

45. Sheridan SC. The redevelopment of a weather type classification scheme for North America. Int J Climatol. 2002;22:51-68.

46. Kalkstein L, Sheridan SC, Kim KR, Lee JS. Evaluating climate change impacts on human mortality in Korean cities: challenges and findings. American Meteorological Society, 20th International Congress of Biometeorology, September 28-October 2, 2014, Cleveland, Ohio. 2014. http://ams.confex.com/ams/ICB2014/ webprogram/Paper252663.html. Accessed 8 Jan 2015.
47. Vanos J, Kalkstein L, Sailor D, Shickman K, Sherdian S. Health impacts of urban cooling strategies in Baltimore, Los Angeles, and New York City. Global Cool Cities Alliance. 2014. http://www. coolrooftoolkit.org/knowledgebase/health-impacts-of-urbancooling-strategies-in-baltimore-los-angeles-and-new-york-city. Accessed 9 Jan 2015

48. Vanos JK, Cakmak S, Kalkstein LS, Yagouti A. Association of weather and air pollution interactions on daily mortality in 12 Canadian cities. Air Qual Atmos Health. 2014. doi:10.1007/s11869-014-0266-7.

49. Kalkstein L, Sailor D, Shickman K, Sherdian S, Vanos J. Assessing the health impacts of urban heat island reduction strategies in the District of Columbia. Report DDOE ID\#2013-10-OPS, Global Cool Cities Alliance. 2013. Quantification of heat-health benefits from implementing cool-cities measaures.

50. Nowak DJ, Heisler GM. Air quality effects of urban trees and parks. Research Series 2010, National Recreation and Park Association. 2010. http://www.nrpa.org/uploadedFiles/nrpa. org/Publications and Research/Research/Papers/NowakHeisler-Research-Paper.pdf. Accessed 15 Feb 2015.

51. Taha H, Akbari H, Rosenfeld A. Heat island and oasis effects of vegetative canopies: micrometeorological field-measurements. Theor Appl Climatol. 1991;44:123-38. doi:10.1007/BF00867999.

52. Taha H. Ranking and prioritizing the deployment of communityscale energy measures based on their indirect effects in California's climate zones. Report prepared by Altostratus Inc. for the California Energy Commission, PIER Energy-Related Environmental Research. 2013. http://www.energy.ca.gov/2011 publications/CEC500-2011-FS/CEC-500-2011-FS-021.pdf. Accessed 16 Feb 2015.

53. Bell ML, McDermott A, Zeger SL, Samet JM, Dominici F. Ozone and short-term mortality in 95 U.S. urban communities, 1987-2000. JAMA. 2004:292:2372-8.

54. Ito K, De Leon SF, Lippman M. Associations between ozone and daily mortality: a review and an additional analysis. Epidemiology. 2005;16:446-57.

55. Jerrett M, Burnett RT, Pope CA, Ito K, Thurston G, Krewski D, et al. Long-term ozone exposure and mortality. N Engl J Med. 2009;360:1085-95. doi:10.1056/NEJMoa0803894.

56. Barnett AG, Hajat S, Gasparrini A, Rocklov J. Cold and heat waves in the United States. Environ Res. 2012;112:218-24.

57. Basu R. High ambient temperature and mortality: a review of epidemiologic studies from 2001 to 2008. Environ Heal. 2009;8:40. doi:10.1186/1476-069X-8-40.

58. Papanastasiou DK, Melas D, Kambezidis HD. Air quality and thermal comfort levels under extreme hot weather. Atmos Res. 2015;152:4-13. doi:10.1016/j.atmosres.2014.06.002.

59. Poupkou A, Nastos P, Melas D, Zerefos C. Climatology of discomfort index and air quality index in a large urban Mediterranean agglomeration. Water Air Soil Pollut. 2011;222:163-83.

60. Williams S, Nitschke M, Sullivan T, Tucker GR, Weinstein P, Pisaniello DL, et al. Heat and health in Adelaide, South Australia: assessment of heat thresholds and temperature relationships. Sci Total Environ. 2012;414:126-33.

61. Li D, Bou-Zeid E. Synergistic interactions between urban heat islands and heat waves: the impact in cities is larger than the sum of its parts. J Appl Meteorol Climatol. 2013;52:2051-64. doi:10. 1175/JAMC-D-13-02.1. On the exacerbation of heat waves by urban climates and heat islands.

62. Jiang X, Wiedinmyer C, Chen F, Yang Z-L. Predicted impacts of climate and land use change on surface ozone in the Houston, Texas area. J Geophys Res. 2008;113, D20312. doi:10.1029/2008JD009820.

63. Wang X, Chen F, Wu Z, Zhang M, Tewari M, Guenther A, et al. Impacts of weather conditions modified by urban expansion on surface ozone: Comparison between the Pearl River Delta and Yangtze River Delta regions. Adv Atmos Sci. 2009;26:962-72. On the exacerbation of ozone air-quality problem by urban climate and heat islands. 
64. Tan J, Zheng Y, Tang X, Guo C, Li L, Song G, et al. The urban heat island and its impact on heat waves and human health in Shanghai. Int J Biometeorol. 2010;54:75-84. doi: 10.1007/s00484-009-0256-x.

65. Goggins WB, Chan EYY, Ng E, Ren C, Chen L. Effect modification of the association between short-term meteorological factors and mortality by urban heat islands in Hong Kong. PLoS ONE. 2012;7, e38551. doi:10.1371/journal.pone.0038551.

66. Adachi SA, Kimura F, Kusaka H, Inoue T, Ueda H. Comparison of the impact of global climate changes and urbanization on summertime future climate in the Tokyo metropolitan area. J Appl Meteorol Climatol. 2012;51:1441-54. doi:10.1175/JAMC-D-11-0137.1.

67. Potchter O, Ben-Shalom HO. Urban warming and global warming: combined effect on thermal discomfort in the desert city of Beer Sheva, Israel. J Arid Environ. 2013;98:113-22. doi:10.1016/j. jaridenv.2013.08.006.

68. Lemonsu A, Kounkou-Arnaud R, Desplat J, Salagnac J-L, Masson V. Evolution of the Parisian urban climate under a global changing climate. Clim Chang. 2013;116:679-92. doi:10.1007/s10584-0120521-6.

69. Penrod A, Zhang Y, Wang K, Wu S-Y, Leung LR. Impacts of future climate and emission changes on U.S. air quality. Atmos Environ. 2014:89:533-47.

70. Taha H. Potential impacts of climate change on tropospheric ozone in California: a preliminary assessment of the Los Angeles basin and the Sacramento valley. Lawrence Berkeley National Laboratory Report LBNL-46695, Berkeley, California. 2001. http:// escholarship.org/uc/item/5s41x609. Accessed 16 Feb 2015.

71. Wu S, Mickley LJ, Jacob DJ, Rind D, Streets DG. Effects of 20002050 changes in climate and emissions on global tropospheric ozone and the policy relevant background surface ozone in the United States. J Geophys Res. 2008;113, D18312. doi:10.1029/ 2007JD009639.

72. Horton DE, Skinner CB, Singh D, Diffenbaugh NS. Occurrence and persistence of future atmospheric stagnation events. Nat Clim Chang Lett. 2014; 4 doi: 10.1038/NCLIMATE2272.

73. Zlatev Z. Impact of future climatic changes on high ozone levels in European suburban areas. Clim Chang. 2010;101:447-83. doi:10. 1007/s10584-009-9699-7.

74. Jacob DJ, Winner DA. Effect of climate change on air quality. Atmos Environ. 2009;43:51-63.

75. Kleeman M. A preliminary assessment of the sensitivity of air quality in California to global change. Clim Chang. 2009;87:S273-92. doi:10.1007/s10584-007-9351-3.

76. U.S. Environmental Protection Agency. Assessment of the impacts of global change on regional U.S. air quality: a synthesis of climate change impacts on ground-level ozone. EPA 600-R-07-094F, Office of Research and Development, National Center for Environmental Assessment, Research Triangle Park, NC; 2009.

77. Sailor DJ, Kalkstein LS, Wong E. The potential of urban heat island mitigation to alleviate heat related mortality: methodological overview and preliminary modeling results for Philadelphia. In: Proceedings of the 4th Symposium on the Urban Environment 4 (May 2002), 68-69, Norfolk, VA; 2002.

78. Doick KJ, Peace A, Hutchings TR. The role of one large greenspace in mitigating London's nocturnal urban heat island. Sci Total Environ. 2014;493:662-71. doi:10.1016/j.scitotenv.2014.06.048.

79. Fallmann J, Emeis S, Suppan P. Mitigation of urban heat stress - a modeling case study for the area of Stuttgart. Erde. 2013;144: 202-16

80. Saneinejad S, Moonen P, Carmeliet J. Comparative assessment of various heat island mitigation measures. Build Environ. 2014;73: 162-70. doi:10.1016/j.buildenv.2013.12.013.

81. Kalkstein LS, Sheridan SC. The impact of heat island reduction strategies on health-debilitating oppressive air masses in urban areas. Phase 1. U.S.: EPA Heat Island Reduction Initiative; 2005. $26 \mathrm{p}$.

82. Nowak DJ, Civerolo KL, Rao ST, Sistla G, Luley CJ, Crane DE. A modeling study of the impact of urban trees on ozone. Atmos Environ. 2000;34:1601-13.

83. Anderson GB, Bell ML, Peng RD. Methods to calculate the heat index as an exposure metric in environmental health research. Environ Health Perspect. 2013;121:1111-9. doi:10.1289/ehp. 1206273.

84. National Weather Service. Meteorological conversions and calculations: Heat index calculator. 2015. http://www.hpc.ncep.noaa.gov/ $\mathrm{html} /$ heatindex_equation.shtml. Accessed $30 \mathrm{Jan} 2015$.

85. Jendritzky G, de Dear R, Havenith G. UTCI - why another thermal index? Int J Biometeorol. 2012;56:421-8. doi:10.1016/j.atmosenv. 2014.01.001.

86. Stone Jr B, Vargo J, Liu P, Habeeb D, DeLucia A, Trail M, et al. Avoided heat-related mortality through climate adaptation strategies in three US cities. PLoS ONE. 2014;9, e100852. doi:10.1371/ journal.pone.0100852.

87. Ma H, Shao H, Song J. Modeling the relative roles of the Foehn wind and urban expansion in the 2002 Beijing heat wave and possible mitigation by high reflective roofs. Meteorog Atmos Phys. 2014;123:105-14.

88. Chen D, Wang X, Thatcher M, Barnett G, Kachenko A, Prince R. Urban vegetation for reducing heat related mortality. Environ Pollut. 2014;192:275-84. doi:10.1016/j.envpol.2014.05.002.

89. Eder B, Kang D, Rao ST, Mathur R, Yu S, Otte T, et al. Using national air quality forecast guidance to develop local air quality index forecasts. Bull Am Meteorol Soc. 2010;91:313-26. doi:10. 1175/2009BAMS2734.1.

90. Akbari H. Energy saving potentials and air quality benefits of urban heat island mitigation. Lawrence Berkeley National Laboratory Report No. 58285. 2005. www.osti.gov/scitech/biblio/860475. Accessed 20 Dec 2014.

91. Taha H, Sailor D. Evaluating the effects of radiative forcing feedback in modeling urban ozone air quality in Portland, Oregon: Twoway coupled MM5-CMAQ simulations. Bound-Layer Meteorol. 2010;137:291-305. doi:10.1007/s10546-010-9533-9. 